\title{
Secondary School Teachers' Understanding of Energy Flow in Ecosystems: Carbon Sink and Sequestration Perspective
}

\author{
Evans L. Chimoita ${ }^{1 *}$, Herman E. Embeywa ${ }^{2}$ and Joseph P. Gweyi-Onyango ${ }^{3}$ \\ ${ }^{1}$ Department of Agricultural Economics, Agricultural Education and Extension Programme, \\ University of Nairobi, P.O Box 30197, Nairobi, Kenya \\ ${ }^{2}$ Department of Agricultural Science and Technology, Kenyatta University, \\ P O Box 43844-00100, Nairobi Kenya \\ ${ }^{3}$ Department of Mathematics and Science Education, Masinde Muliro University of Science \\ and Technology, P.O Box 190-50100, Kakamega, Kenya
}

KEYWORDS Biology Teachers. Ecosystems. Carbon Credits. Carbon Sequestration. Energy

\begin{abstract}
The energy and other environmental conservation measures are emerging issues of concern all across the world. The awareness on climate change and sustainable environmental resource utilization are being discussed globally in all sectors of development. It is for this reason; the study investigated Kenyan biology teachers' understanding of soil carbon sink and sequestration in Kenyan ecosystems as emerging issues. The study aimed at relating biology teaching content to a wider scope of energy flow in ecosystem; a subject taught and assessed by teachers of different secondary schools in Kenya. The study employed descriptive research design. Twenty- four (24) secondary school teachers were randomly selected and sampled from thirty- six (36) secondary schools of Lugari District in Kenya. Self-valuation questionnaire (SVQ) was used to capture key information on understanding of soil carbon sequestration as some of the emerging issues in terrestrial ecosystems. The results revealed a rich understanding of green house effects on the general environment among teachers assessed. A high percentage of the teachers demonstrated understanding climate changes phenomena in their response (21\%). However, a high percentage (71\%) of selected and assessed teachers lacked clear grasp on carbon sequestration concepts and phenomena beyond photosynthesis process. Further, the teachers' demonstrated poor understanding of premiums paid by industrialized nations in a bid to mitigate environmental pollution, particularly via Green House Gases (GHGs) (70\%). The study, in conclusion revealed that, there was a general ecosystems knowledge gap among biology teachers in Kenyan secondary schools concerning emerging issues particularly in ecology and is, therefore, important that they get updates by undergoing refresher courses as a means of strengthening their competencies. It is also probable that the teachers may have acquired the misconceptions during the period of study or it was an indirect manifestation of complexes of interrelations between biological processes.
\end{abstract}

\section{INTRODUCTION}

There exist documented studies investigating students' understanding of fundamental biological concepts such as inheritance, human biology, natural selection, human circulatory system, nutrient cycling in ecosystems (Adeniyi 1985) and this misconception have been reported amongst undergraduate ecology students (Boyes and Stanisstreet 1991). In addition, though not limited to specific age group or particular discipline, available studies have revealed deficiency of knowledge in the teachers understanding of soil carbon sequestration carbon trading as an emerging issue in ecosystems (Llyas 2011). It has also been shown that the teach-

Address for correspondence:

Telephone: +254721304962

E-mail: echimoita@uonbi.ac.ke,

echemoita@yahoo.com ers could have played a role in the formation of misconceptions held by their students (Sanders 1993). Further, she suggested that, assessment strategies used by biology teachers could be a factor influencing the development of misconceptions in their students. It was, therefore, imperative to assess teachers' scope in energy flow which encompassed a number of biological concepts. This is because the teachers' awareness and understanding on globally emerging issues especially in ecology is important because they encounter a large number of Kenyan students population and they also disseminate bulk of information that can positively impact on climate change measures (Ugulu et al. 2008).

The government of Kenya in conjunction with government of Japan through Japan International Cooperation Agency (JICA), an international project entitled "Strengthening Mathematics and Science in Secondary Education" (SMASSE) carried out a baseline survey on ped- 
agogical aspects in science and mathematics education in selected Kenyan secondary schools. The report highlighted that inappropriate teaching methods and approaches were the reasons for poor understanding and performance of the students in science and mathematics education in the selected secondary schools (SMASSE 2003). In addition, the report further highlighted that science and mathematics teachers lacked in-service trainings particularly in their areas of specialization after their initial training. This could explain the lack of awareness on emerging issues in their areas of specialization (Odhiambo 2011).

Information on the emerging issues in science and technology plays a vital role in national development both in the developed and developing countries. To achieve this, governments must include the current research findings and emerging issues in the school curricula to realize various educational reforms in such areas (Osborne and Simon 2003). In Africa, for instance, the African Primary Science Program (APSP) was developed. The experience of the APSP has led to the evolution of Science Education Program for Africa (SEPA). Besides, the studies have revealed that application of devices, machines techniques for manufacturing and or well productive processes have brought changes in the whole world in terms of living standards. It is on this basis that people tend to understand new development and changes in their environment (Peter et al. 2011).

Carbon dioxide is continually exchanged between aquatic, terrestrial ecosystems and the atmosphere through photosynthesis, respiration and decomposition (Brown et al. 1993). Khatete (1995) pointed out that, Kenyan secondary school biology teachers teach photosynthesis concepts to Kenyan secondary schools student based on the syllabus and rarely make further references outside the syllabus. The study revealed that the teachers provide explanation of various photosynthetic products in leaves, branches, stems, roots and other organs but fail to explain to students the fate of dead end organic carbon after decomposition and respiration. Whereas photosynthesis results in the conversion of carbon IV oxide into organic carbon in growing plants, decomposition releases gaseous back into the atmosphere as a gas. Impounded carbon is also lost through cellular respiration and decomposition of dead plant mate- rial increasing leaf litter and shed (Brown et al. 1993). Carbon credit is a unit of carbon stored in newly established forest biomass or soil and may be purchased as a means to offset carbon dioxide emissions (Ficher 2007). The most rapid rate of sequestration into organic materials occurs during early tree growth. Carbon credit is a generic term for any tradable certificate or permit representing the right to emit one tone of carbon or carbon dioxide equivalent (tCO2e) (Christian 2006). Carbon credits and carbon markets constitute a component of national and international attempts to mitigate the growth in concentrations of greenhouse gases (GHGs). One carbon credit is equal to one ton of carbon dioxide, or in some markets, carbon dioxide equivalent gases. Carbon trading is an application of an emissions trading approach. The global warming is believed to be caused by a phenomenon known as the "greenhouse effect," which is an important natural process regulating and maintaining the earth's climate (Karani, 2002). Rapid increases in the atmospheric levels of $\mathrm{CO}_{2}$ due to human activity such as the burning of fossil fuels and deforestation result in increased amounts of radiant heat trapped near the earth's surface. It is predicted that this interferences gradually increases the mean global temperature, causing dramatic climatic changes and as such, the atmospheric levels of $\mathrm{CO}_{2}$ increases (Woomer 2003). Greenhouse gas emissions are capped and then markets are used to allocate the emissions among the group of regulated sources. The goal is to allow market mechanisms to drive industrial and commercial processes in the direction of low emissions or less carbon intensive approaches than those used when there is no cost to emitting carbon dioxide and other Green House Gases (GHSs) into the atmosphere.

Since GHG mitigation projects generate credits, this approach can be used to finance carbon reduction schemes between trading partners and around the world. There are also many companies that sell carbon credits to commercial and individual customers who are interested in lowering their carbon footprint on a voluntary basis (Karani 2002). Actually, little information exists on the amount carbon soil can store and how each of these and other factors affects this storage (Campbell 2010). Besides, to collect information on this subject, in addition to those areas currently being studied, that is, soil carbon 
fluxes resulting from management practices rhizosphere carbon microclimate, will have to be better understood before the extent of forestry's contribution to global greenhouse gas reductions could be defined (Brown et al. 1993). It should also be emphasised that teachers across the world should be engaged in these carbon reduction schemes to educate the larger populace of the students. Researches should be conducted for improvement of the conceptualization of the terrestrial carbon cycle and its effects on land use practices, coupled with the growing incentive to remove carbon dioxide from the atmosphere through natural processes. This could improve the incentive for landowners, learners and teachers to practice forestry, (Campbell 2010). Carbon payments have the potential to be the primary motivation for storing carbon in forests (Woomer 2003). It is for this reason that, the study sought to unearth biology teachers' understanding of soil carbon sequestration and carbon credits as an emerging issue in ecosystems and the world at large.

\section{RESEARCH METHODS}

\section{Study Area}

The study was conducted in Lugari district in Kakamega county Kenya as illustrated by Figure 1. Lugari district is situated on the western part of the Rift Valley province of Kenya. On Northern side, Lugari borders Trans-Nzioa district and on the West it boarders Bungoma West district and in the South lies Kakamega North district.

The study employed descriptive design. Twenty four secondary school teachers were randomly drawn from thirty six secondary schools of Lugari district. A self developed valuation questionnaire on understanding of soil carbon sequestration as an emerging issue in ecosystems was used a tool of study among biology teachers. To obtain the population of biology teachers, the principals were contacted. For single and double streamed schools one and two biology teachers were purposely selected respectivelv.

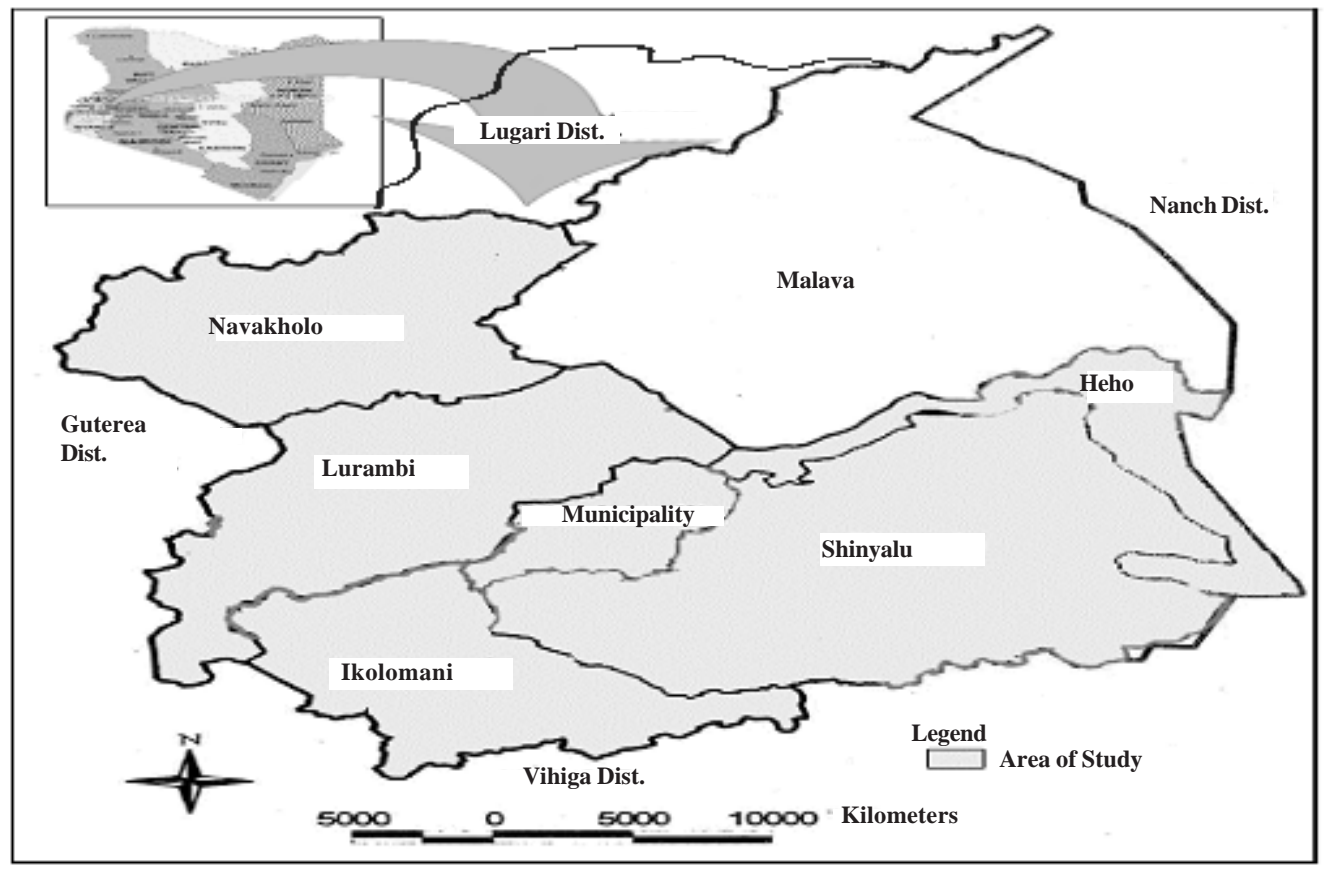

Fig. 1. Study area map

Source: The Government of Kenya, The central education administrative divisions of Western province. Ministry of Planning and Vision 2030; Map series No. 14, Ministry of Education, Nairobi, Kenya 
In schools with more than three streams, two biology teachers were selected. The (SVQ) was duly vetted by specialists from biological sciences, environmental sciences and evaluation and science education departments of Masinde Muliro University of Science and Technology. In total the researcher collected data from twenty four biology teachers from Lugari secondary schools. The data obtained was analyzed using Statistical Package for Social Sciences (SPSS) version 20 . The data was then presented using descriptive statistics and tables.

\section{RESULTS AND DISCUSSION}

The study sought to test an array of terrestrial photosynthetic carbon issues and concepts indicated as $X_{1}$ to $X_{12}$ in relation to soil carbon sink and sequestration. The carbon IV Oxide issue has been in public domain over the years, particularly, in relation to global warming and soil carbon enrichment. The teachers' opinion was rated as: Yes; meaning the teachers' high mastery of concepts, No; meaning the teachers' poor understanding of concepts, and No idea; meaning teachers had no idea about the concepts.

There was no clear expressed teachers' understanding of the new concepts in ecosystems in rating, particularly in regard to general soil dynamics. Similar trend in response in terms of support in carbon flow was displayed (Table 1). However, majority (54\%) had no idea whether there was accumulation of carbon in soil, which had impact on soil ecosystem like microbial pop- ulation. The questions in Table 1 were very much related and the responses were very consistent. The fact that a big proportion did not get them right ("No" plus "No idea”) constituted an average of $70 \%$ in all concepts. This is no surprise as studies Turkey revealed that regardless of age and level of schooling, misconception is prevalent in understanding and interpreting biological concepts; including University graduates (Çapa 2000; Özkan 2001; Sungur et al. 2001).

Results (Tables 1 and 2) revealed conflicting and inconsistent responses from the teachers assessed, despite the concepts tested were very much related. There was striking similarities in the trends in teachers understanding of soil carbon dynamics $\left(\mathrm{X}_{1}\right)$, and concepts which stated that clearing of old plant growth and native forests reduce carbon accumulation in soil $\left(\mathrm{X}_{4}\right)$ in Table 2, that carbon pollution will decline by $5 \%$ by $2030\left(X_{7}\right)$ (Table 3$)$.

In concepts $\left(\mathrm{X}_{11}\right)$ Microbial activities affects soil ecosystem and soil nutrient status, there was similarities where the responses based on the rating above. In another category were $\left(\mathrm{X}_{3}\right)$ teachers support plant-soil carbon flow hypothesis: $\left(\mathrm{X}_{6}\right)$ - rapid wholesale carbon pollution will reduce ecosystem dynamics: $\left(\mathrm{X}_{0}\right)$ - Trees reduce greenhouse effects and $\left(\mathrm{X}_{12}\right)$ - there is common understanding between plant activity and microbial actions difference in teachers opinion.

In Table 2, the best understood concepts among the teachers included an understanding that afforestation and reforestation offsets greenhouse effect (70\%) but could not be related it

Table 1: Teachers awareness level and understanding of new concepts in ecosystems

\begin{tabular}{lcccc}
\hline Concept & \multicolumn{3}{c}{ Teachers opinion rate } \\
\cline { 2 - 5 } & Yes & No & No idea & Total \\
\hline Teachers understanding of soil carbon dynamics $\left(\mathrm{x}_{1}\right)$ & 7 & 9 & 8 & 24 \\
Accumulation of carbon in soil has impact on soil ecosystem $\left(\mathrm{x}_{2}\right)$ & 7 & 4 & 13 & 24 \\
Teachers support of plant to soil carbon flow hypothesis $\left(\mathrm{x}_{3}\right)$ & 6 & 8 & 10 & 24 \\
\hline
\end{tabular}

$\mathrm{N}=24$; Opinion rating: Yes, No, No idea

Table 2: Teachers awareness level and understanding of new concepts in ecosystems

\begin{tabular}{lcccc}
\hline Concept & \multicolumn{3}{c}{ Teachers opinion rate } \\
\cline { 2 - 5 } & Yes & No & No idea & Total \\
\hline Clearing of old plant growth and native forests reduce carbon & 7 & 8 & 9 & 24 \\
$\quad$ accumulation in the soil $\left(\mathrm{x}_{4}\right)$ & 17 & 7 & 0 & 24 \\
Afforestation and reforestation offset greenhouse effect $\left(\mathrm{x}_{5}\right)$ & 6 & 11 & 7 & 24 \\
Rapid wholesale of carbon pollution will reduce ecosystems $\left(\mathrm{x}_{6}\right)$ & & & 7 \\
\hline
\end{tabular}

$\mathrm{N}=24$; Opinion rating: Yes, No, No idea 
with $\left(\mathrm{x}_{6}\right.$; that carbon pollution would reduce ecosystems dynamics (21\%). This could probably, as a result, intensive work by KAFOPAMA that developed Participatory Management Plan for Kakamega Forest that aimed at bringing together the communities living around Kakamega forest, Kenya Wildlife Services (KWS), and Department of Forest in collective afforestation and reforestation activities in areas surrounding the forest and within the forest itself, with both indigenous and exotic tree species (Karani 2002; 2004). The current work was carried out in Kakamega, which is the same area and this may explain the teachers' understanding of the benefits of the afforestation and reafforestation. On the contrary, the support of plant to soil carbon flow hypothesis (Table 1) and carbon pollution (Table 2) were the least understood concept in this category. This could be attributed to the Kenyan 8.4.4 secondary school syllabus which confines teachers to specific concepts of the ecosystem (SMASSE 2003). It was revealed that teachers who had no idea of the concepts in this study were more than those who had a better understanding of these fundamental concepts. This could be associated with lack of exposure to current trends in ecosystems and inexperience or deficiencies in quest for new knowledge in ecology, just as reported for children (Khatete 1995). In addition to lack of time, low interest among contributed to this performance (SMASSE 2003). Indeed, previous works have demonstrated that teachers play a strong direct role in the formation of misconceptions held by their students (Sanders 1993; Yip 1998).

The results revealed teachers' inability to fully comprehend the concept of energy flow between plant-soil sink in relation to $\mathrm{CO}_{2}$ enrichment which is an issue relating to carbon credit.

Further, teachers' demonstrated poor understanding on whether accumulation of carbon in the soil has impact on soil ecosystem $\left(\mathrm{X}_{2}\right)$ and that microbial activity affects soil ecosystem and soil nutrients. The teachers' supported opinion that there is plant-soil carbon flow hypothesis (X3) and that $\left(\mathrm{X}_{12}\right)$, there is a possible cross-talk between plant activity and microbial actions. It is a common piece of knowledge that climate change is taking place. Green-house gas levels are rising and are now at their highest concentration for more than 400,000 years, (Carbon Fund 2003).

This increase was attributed to human activities and other natural climatic phenomenal changes. This trend is accounting for about $80 \%$ human caused carbon dioxide emission and 20\% by photosynthetic processes. The above activities may explain why we have a common understanding among teachers in concepts $\mathrm{X} 1, \mathrm{X}_{4}, \mathrm{X}_{7}$ and $\mathrm{X}_{10}$. However, climate changes input on biodiversity are already evident by shifting and migration changes of insects, animals, modified flowering and fruiting cycles, species extinction, drought, flood induced die back and invasion of new species as obvious indicators of hypothesis $\left(X_{4}\right)$ (Campbell 2010). Concepts relating to concepts $X_{1}, X_{4}, X_{7}$ and $X_{10}$ in (Tables 1, 2, 3 and 4) had majority of teachers' stating common understanding. However, this was interesting because many teachers could not link emerging issues in ecosystems and their theoretical understanding which they explicitly supported in concept $\left(\mathrm{X}_{3}\right)$ as illustrated in Table 3 .

Explanation supporting increased input of carbon to soil and influences on soil organic matter processes and micro-organic was clear among the teachers as depicted in $\left(\mathrm{X}_{11}\right)$, where the teachers were able to commend whether microbial activity affects soil ecosystem and soil nutrient status. Majority of teachers (70\%) concurred that the amount and activities of soil micro-organisms may change $\left(\mathrm{X}_{9}\right)$, which may accelerate nutrients mineralization in soil and increase plant nutrients supply. Further, changes in litter components may also increase biota,

Table 3: Teachers' understanding of greenhouse effects on ecosystems

\begin{tabular}{lrrr}
\hline Concept & & \multicolumn{2}{c}{ Teachers opinion rate } \\
\cline { 2 - 4 } & Yes & No & No idea \\
\hline Carbon pollution will decline by 5\% by year $2030\left(\mathrm{x}_{7}\right)$ & 2 & 9 \\
$\begin{array}{l}\text { Excess sink of photosynthetic carbon in soil can cause micro- } \\
\quad \text { climatic change and invasion by alien species }\left(\mathrm{x}_{8}\right)\end{array}$ & 15 & 2 & 24 \\
Trees reduce greenhouse effects $\left(\mathrm{x}_{9}\right)$ & 17 & 7 & 24 \\
\hline
\end{tabular}

$\mathrm{N}=24$; Opinion rating: Yes, No, No idea 
particularly the amount and activity of heteronutritional bacteria. Concerning whether there was existence of concept $\left(\mathrm{X}_{1}\right)$; that, there was across talk between plant actively and microbial actions; a notable number of teachers gave conflicting information as indicated in Table 4.

Carbon stored in soil body may increase, which makes soil potential sink for carbon. This will possibly mitigate the increase of carbon dioxide in the atmosphere. Explanation supporting increased input of carbon to soil and influences on soil organic matter processes and micro-organic was clear among the teachers as depicted in $\left(\mathrm{X}_{11}\right)$, where the teachers were able to commend whether microbial activity affects soil ecosystem and soil nutrients. These effects could be a result of increased soil organic matter carbon fluxes, which have been suggested to result from the interaction of elevated $\mathrm{CO}_{2}$ concentrations and elevated temperature (Butnor et al. 2003, Tingey et al. 2006). Majority of teachers (70\%) concurred that the amount and activities of soil micro-organisms may change $\left(\mathrm{X}_{9}\right)$, which may accelerate nutrients mineralization in soil and increase plant nutrients supply. Further, the changes in litter components may also increase biota, particularly the amount and activity of hetero-nutritional bacteria. On comparison on whether there was hypothesis $\left(\mathrm{X}_{12}\right)$; across the talk between plant activity and microbial actions, many of the respondents gave conflicting information as indicated in Table 4. The few examples we used in current research serve to demonstrate the inherent complexity in soil carbon science. For instance, although the greater productivity above ground always translates into higher soil carbon inputs, such input of fresh labile (easily decomposable) carbon has the potential of stimulating decomposition of older, recalcitrant (difficult to decompose) soil carbon (Cheng et al. 2003; Fontaine et al. 2007), thereby decreas- ing overall soil carbon stocks. In another example of the interrelatedness of factors affecting soil carbon, the overall trend in global soil carbon respiration rates has been an increase in respiration with increasing temperature; however, it is unclear if that trend is offset by higher inputs from higher productivity (Bond-Lamberty et al. 2010). Although, generally carbon is likely to be sequestered in lands converted from agriculture to forests and in existing forests in temperate zones (Post et al. 2000), such as U.S. northeastern forests (Goulden et al. 1996), quantification of soil carbon dynamics remain problematic. All these concerns make it difficult to specifically say that teachers lack the understanding of the concept. In any case, their background trainings, particularly the books used during their training have a lot of bearing. The previous work suggested that another factor that contributes to the occurrence of misconceptions by students is textbooks, which include many errors and incorrect information (Storey 1991, 1992).

\section{CONCLUSION}

Research findings unearthed that a high percentage of biology teachers selected in this study had no idea concerning soil carbon sinks and sequestration concepts. In addition, teachers had no idea whether free permits or premiums must be given by heavily polluting industrial nations to save our ecosystems. It was disclosed that quite a number of biology teachers do not update themselves on emerging issues in their areas of profession as revealed by inconsistent responses demonstrated in their responses. The knowledge gap among teachers was attributed to biology teachers in Kenyan secondary schools not updating themselves on emerging issues in their areas of profession particularly ecosystems.

Table 4: Teachers' opinion of organic carbon on soil ecosystems

\begin{tabular}{|c|c|c|c|c|}
\hline \multirow[t]{2}{*}{ Concept } & \multicolumn{4}{|c|}{ Teachers opinion rate } \\
\hline & Yes & No & No idea & Total \\
\hline $\begin{array}{l}\text { There is relationship between photosynthesis and soils in } \\
\text { terms of microbial activities }\left(\mathrm{x}_{10}\right)\end{array}$ & 14 & 2 & 8 & 24 \\
\hline $\begin{array}{l}\text { Microbial activity affects soil ecosystem and soil nutrient status }\left(\mathrm{x}_{11}\right) \\
\text { There is possible cross talk between plant activity and }\end{array}$ & 17 & 7 & 0 & 24 \\
\hline microbial actions $\left(\mathrm{x}_{12}\right)$ & 8 & 7 & 9 & 24 \\
\hline
\end{tabular}

$\mathrm{N}=24$; Opinion rating: Yes, No, No idea 
This was compounded by lack of time and teachers inability for new knowledge and information quest in the area of specialization.

\section{ACKNOWLEDGEMENTS}

Our sincere gratitude and thanks go to students who participated in the study. Very special thanks to the teachers in Lugari district who not only participated in the study but also responded to questions. We also want to thank Masinde Muliro University of Science and Technology for the logistics and supports extended to us.

\section{REFERENCES}

Andeniyi E 1985. Misconcemptions of selected ecological concepts held by some Nigerian students. Journal of Biological Education, 19: 311-316.

Bond-Lamberty B, Thomson A 2010. Temperatureassociated increases in the global soil respiration record. Nature, 464: 579-582.

Boyes E, Stanisstreet M 1991. Misconceptions in firstyear undergraduate science students about energy sources for living organisms. Journal of Biological Education, 25(3): 208-213.

Brown S, Hall C, Knabe WR, Trexler W, Woomer P 1993. Tropical forests: Their past, present and future role in the terrestrial carborn budget. Water, Air, Soil Pollution, 71-94.

Butnor JR, Johnsen KH, Oren RAM, Katul GG 2003. Reduction of forest floor respiration by fertilization on both carbon dioxide-enriched and reference 17year-old loblolly pine stands. Global Change Biology, 9: 849-861.

Campbell B 2010. The United Nations Food Agenda and Farming Research Groups in Helping Farmers Cut Carbon Emmissions. The Standard Newspaper Daily, P. 20.

Capa Y 2000. An Analysis of $9^{\text {th }}$ Grade Student's Miseoneeptions Concerning Photosynthesis and Respiration in Plants. Mater's Thesis. Ankara: Middle East Teehnieal University.

Carbon Fund 2003. Carbon Sequestration: Developing Forest Accounting Principles that are Effective and Sequestrate Carbon and Improve Biodiversity. A Program From <http://www. the carbonfund.org $>$ (Retrieved on 13 July 2013).

Cheng W, Johnson DW, Fu S 2003. Rhizosphere effects on decomposition: Controls of plant species, phenology, and fertilization. Soil Sci Soc Am J, 67: 1418-1427.

Christian A 2006. Carbon capture and storage from fossil fuels and Biomass-costs and potential role in stabilizing the atmosphere. Journal of Biological Education: Climate Change, 74: 47-49

Fisher B 2007. Issue Related to Mitigation in the Long Term Context. Cambridge: Cambridge University Press.

Fontaine S, Barot S, Barre P, Bdioui N, Mary B, Rumpel C 2007. Stability of organic carbon in deep soil layers controlled by fresh carbon supply. Nature, 450: 277-280.
Goulden ML, Munger JW, Fan SM, Daube BC, Wofsy SC 1996. Measurements of carbon sequestration by long-term eddy covariance: Methods and a critical evaluation of accuracy. Global Change Biology, 2: 169-182.

Karani P 2002. Introduction to Emerging Carbon Offset Markets: Prospects and Challenges for Development in Africa. Nairobi: College Publishers Limited.

Karani P 2004. Afforestation, Reforestation and Forest Management: Natural Resource Conservation, Management and Carbon Sequestration within the Scheme of Payment for Environmental Services (PES): Bureau of Environmental Analysis International (BEA-International). From <www. 6wax F51kybQ> (Retrieved on 13 July 2013).

Khatete D 1995. Children's Understanding of Decomposition and its Importance in Nature Among Some Kenyan Children. Leeds: Leeds University Press.

Llyas K 2011. Are we Ready for Carbon Trading? Internationally, Carbon Trading has become a Money Spinner. Nairobi: Standard.

Odhiambo J 2011. Carbon Credit Trading Exchange Timely. Nairobi: Standard Publishers.

Osborne J, Simon S 2003. Attitudes towards science: A review of literature and its implications. International Journal of Science Education, 1049-1079.

Özkan Ö 2001. Remediation of Seventh Grade Students' Misconceptions Related to Ecology Concepts Through Conceptua1 Change Text Approach. Master's Thesis, Unpublished. Ankara: Middle East Technica1 University.

Peter L, Jasan G, Audberto Q 2011. How Kenya can Reap from Carbon Credits. Nairobi: Daily Publishers.

Post WM, Kwon KC 2000. Soil carbon sequestration and land-use change: Processes and potential. Global Change Biology, 6: 317-327.

Sanders M 1993. Erroneous ideas about respiration: The teacher factor. Journal of Research in Science Teaching, 30(8): 919-934

SMASSE 2003. Resources and Facilities for Teaching and Learning Biology. Nairobi: University Press.

Storey RD 1991. Textbook errors and misconceptions in biology: Cell metabolism. American Biology Teacher, 53(6): 339-343.

Storey RD 1992. Textbook errors and misconceptions in biology: Cel1 energetics. American Biology Teacher, 54(3): 161-166.

Sungur S, Tekkaya C, Geban Ö 2001. The contribution of conceptual change texts accompanied by concept mapping to students' understanding of the human circulatory system. School Science and Mathematics, LO1(2): 91-101.

Ugulu J, Aydin H, Yorek N, Dogan N 2008. The impact of endemism concept on environmental attitudes of secondary school students. Natural Montenegrima, 165-173.

Tingey DT, Lee EH, Waschmann R, Johnson MG, Rygiewicz PT 2006. Does soil $\mathrm{CO}_{2}$ efflux acclimatize to elevated temperature and $\mathrm{CO}_{2}$ during long-term treatment of Douglas-fir seedlings? New Phytologist, 170: 107-118.

Woomer P 2003. Estimating Carbon Stock in Smallholder Agricultural Systems. Nairobi: Technologies Publishers.

Yip DY 1998. Teachers' misconceptions of the circulatory system. Journal of Biological Education, 32(3): 207-216. 